\title{
ASSESSING THE INFLUENCE OF NOISE ON THE PERFORMANCE OF OPEN AND CLOSED OFFICE WORKERS IN ENUGU STATE, NIGERIA
}

\author{
Arc.Offor Justus Nwafor, Ph.D \\ Department of Architecture, \\ Enugu State University of Science \& Technology (ESUT) \\ Enugu State, Nigeria \\ justus.nwafor@esut.edu.ng \\ 08034034120
}

\section{Abstract}

The issue of noise in office buildings is becoming more problematic with the extensive use of open plans concept in building design. Acoustic comfort in buildings is the capacity to protect occupants from noise. Despite the increasing problems ofnoise research works have shown that not much attention is devoted to acoustic related issues during building design stages (Andersen, Toftum, Andersen and Olesen, 2009, Andersen, 2008). The general apathy to acoustic consideration in buildings during design stages leads to post occupancy palliative measures which are more expensive and of less result-oriented. This paper seeks to evaluate the impact of nose on productivity of office workers in Enugu State. The main sources of information explored are extensive review of related literature. Objective and self-rating survey instruments of measurement were adopted. Descriptive statistical analysis was used determine the influence of noise on efficiency of workers. Result of the analysis showed that noise in an office building can reduce the rate of performance of office workers. Possible recommendations on how to improve acoustic especially in new buildings are made.

Keywords: Acoustic comfort, post occupancy, open plan concept, correlation analysis, Survey Instrument

\subsection{Introduction.}

The design and construction of buildings is targeted towards achieving some specific purposes. But unfortunately most often, these intended objectives are not actualized and thereby affecting the running cost, occupant's performance, health, safety and comfort (Morkporkpor, Daniel and Augustus, 2017). Among the objectives of building designs is comfort of users. The various aspects of comfort are fundamental and paramount on the priority list due to their link with human concentration and productivity. The comfort of building occupants is mainly comprised of three connected components namely, thermal, acoustics and visual comfort.

Thermal comfort is concerned with the state of the mind which expresses satisfaction with the thermal environment (ASHRAE 55, 2010). On the other hand, acoustic comfort in buildings is the capacity to protect occupants from noise and then offer suitable environment (Yousef, Mohammed, Martha, Ahmed, Amit and Esam, 2016). Visual comfort defines lighting conditions and the views from ones workspace. Studies have shown that insufficient light, especially natural daylight or glare reduces the ability to see objects or details clearly (Leech, Nelson, Burnett, Aaron and Raizenne, 2002). Acoustic comfort is an important attribute of commercial and office building design (Jensen et al,. 2005). This assertion was strengthened by recent studies that also reconfirmed the direct and close relationship between acoustic 
comfort and occupant's productivity in commercial buildings (Landstrom, Akerlund, Kjeliberg and Tesarz, 1995).

With the general growth of open plan concept in office designs, issues of acoustic comfort and privacy have been identified as significant factors impacting on occupant's productivity (Sundstrom, Town, Rice, Osborn and Brill, 1994). In addition, it was concluded that noise is probably the most prevalent source of annoyance in offices and can lead to increased stress for occupants (Evans, Gary and Johnson, 2000; Sundstrom et al,. 1994

In most cases acoustics do not receive the level of design attention as thermal, ventilation and other architectural and engineering considerations (Salter, Powell, Begault and Alavarado, 2003). The most likely reason may be that the causes and consequences of poor acoustical performance are perhaps not adequately understood by designers and building owners (Jensen, Arens and Zagreus, 2005). It is therefore, important to evaluate from large population of office buildings in Enugu State, how occupants perceive their acoustical environments and what areas of office buildings design influence these perceptions. This can form part of the database upon which building designers and owners take their decisions.

\subsection{Problem Statement.}

One of the emerging challenges affecting productivity of office workers in Nigerian cities is acoustic problems. Acoustic problems in office buildings originate from airborne sounds, outdoor noise from adjacent spaces, noise from office equipment and sound of nearby facilities. Comfort of office workers and the consequent improved productivity is one of the primary functions of office buildings. Designers of office buildings employ proper assessment of different aspects of comforts including acoustics as means of achieving these objectives. Part of this problem is lack of proper statistical assessment of the impact of noise on productivity of office workers in urban cities.

\subsection{Aim and Objectives.}

\subsubsection{Aim}

The aim of this paper is to evaluate the effect of noise distraction on task performance of open and closed office workers in Enugu State. These objectives are posited to achieve the aim;

\subsubsection{Objectives}

(a) To assess the influence of Indoor Environmental Quality (IEQ) on acoustic comfort of open and closed office workers in Enugu State.

(b) To assess the effect of noise distraction on the satisfaction of open and closed office workers of Enugu State.

(c) To evaluate the influence of noise distraction on the task performance of open and closed office workers in Enugu State.

\subsection{Review of Related Literature.}

\subsection{Evaluation of Occupants' Acoustic Comfort in Office Buildings.}

The evaluation of buildings post commissioning remains is of the greatest cost-effective measures. This according to research, can improve productivity if properly implemented (Morkporkpor et al,. 2017). Control systems aimed at regulating occupants' comfort are key to indoor environmental quality which has vital implications on the overall building performance and energy consumption. It has been reported from research findings that in both commercial and residential buildings, comfort and satisfaction are not often attainable largely due to complex nature of buildings and their control systems (Koranteng, et al, 2010). One of the efforts to address this challenge is through Post Occupancy Evaluation (POE). 
The effects of these acoustic challenges on office workers could be assessed from two different perspectives; annoyance from various noise sources and then lack of communication privacy (Yousef, et al., 2016). In addition to the usual city noise disturbances, the present use of earphone and other modern electrical machines have increased the level of annoyance. A research on masking Speech in Open-Plan offices concluded that noise from other people talking, telephone ringing and other irregular sounds may create more annoyance and disturbance (Veitch, Bradley, Legault, Norcross and Svec, 2002). Most office buildings in Enugu urban are not exempted from these problems of indoor environmental quality (thermal, acoustic, visual and air quality). Environmental quality has direct effect on the acoustic comfort, health and productivity of the occupants (De-Giuli, Da-Pos and De-Carli, $.2012)$.

\subsection{Noise challenges in an Office Environment; issues of developmental realities.}

Noise is defined as an expression of unwanted sound (Nyunling and Cheung, 2007). The salient question is at what level does sound become noise? Empirically there is no standardized threshold for sound to be associated with noise. But some research findings have stated that sound less than $48 \mathrm{~dB}$ is regarded as a threshold of occupants' comfort and above which it becomes distracting and uncomfortable (Armstrong,1997; Evans and Johnson, 2000). Apart from sound level, there are other factors environmental and personal elements that influence sound. According to Nyunling et al., (2007), the environmental factors include temperature, light and air velocity and personal factors as psychological and physiological attributes. The personal judgment of noise dictates its subjective characteristics. Another characteristics of noise that influences its impact is the source. The sources of noise in most modern office are on the increase because of the level of technology.

Acoustic problem is a major challenges in an office setting either because of inadequate design considerations or due inappropriate location of the office building. During design stage, acoustic is given the least attention among other similar factors like ventilation and thermal comfort. Also during feasibility studies and site considerations, some office buildings are sited in a noise-prone areas like markets and heavy traffic junctions. The effect of acoustic confronting office workers can be grouped into two namely, annoyance and lack of communication privacy. The extent of annoyance and disturbance of noise depends on the level, spectrum and variation with time of noise (AlHorr et al., 2016).

In office environment, noise of irregular sounds like people talking and telephone ringing, create more annoyance and disturbance than continuous regular sounds (Veitch et al., 2002). Office workers are more adaptable to expected and regular sounds than spontaneous and unexpected sounds. Noise disturbances and annoyance are some of the challenges that affect workers' task performance which gradually impacts on the economy of any establishment. Acoustic problems therefore, need to addressed during the design stage like ventilation and thermal comfort. It is cheaper and more effective to control acoustic problems at the design stage. It is at stage that decisions are taken on the activities that will take place at both indoor and outdoor of the office building (Bluyssen, Aris, Dommelen, 2011a).

Some design techniques for noise prevention are absorption of sound by ceiling tiles, blocking of sound using workstation panels and sound covering using electronics (Loewen and Suedfeld, 1992). Despite these design techniques for acoustic comfort, more legal frameworks need to be put in place to guide designers of office and other public spaces. In line with this, Leadership in Energy and Environmental Design (LEED) which is one of the most popular green building guidelines has included acoustic credits as an option (AlHorr et al., 2016). But Schiavon and Altomonte, (2014) argued that acoustic requirements should be made mandatory elements of green building guidelines. Though there are concerted efforts to 
address acoustic challenges in offices, but more research works need to be carried out especially as it affects workers' productivity.

\subsection{Main sources of Noise in an office environment}

A typical office setting faces the challenge of noise pollution from the following sources,

(a) Human generated noise; for instance human conservation and phoneinteraction or discussion.

(b) (b) Machine generated noise; example from fax, photocopiers and ringingphone

(c) Impact noise, like door push and walking on hard surfaces.

(d) Background noise of low frequency like HVAC systems and equipment

Human generated noise poses one of the greatest distraction in office environment as against other sources because it is audible and can be understood (Nyunling et al., 2007). Conversation distractions in an office environment lead to annoyance which is an aspect of discomfort. Noise-based annoyance is explained as a feeling of resentment, displeasure, discomfort, dissatisfaction or offense that occur when noise interfere with someone's thoughts, feelings or daily activities (Passhier, 1993).

Machine generated noise and impact noise in contrast is less distraction and has no content involved Background noise cause even less distraction and has no uniformity.

Though it has been established that office related noise have any impact on physical health, but studies have shown that it brings psychological distractions and annoyance to office workers which may reduce their productivity (Environmental Protection Agency EPA, 1981; Cherow, 1991). Studies have suggested that a few symptoms of discomfort from indoor environment can lead to significant reduction in work performance of occupants (Environmental Protection Agency EPA, 2000). In the face of the great challenges posed by human generated noise, efforts to improve acoustics in an office environment, should therefore focus on minimizing conversation distractions.

\subsection{Activities of office task performance that could be influenced by Noise}

The necessity for acoustic considerations in office buildings is based on the fact that most office tasks require some level of focus or detail to facilitate service delivery (Morkporkpor, Daniel and Augustus, 2017). From research findings, acoustic comfort should provide conditions that facilitate clear communication for speech between occupants (Strelets, Periova, Platonova, Pankova, Romero and Shabab, 2016). Communication is one of the key components of information delivery which is necessary for improved productivity in office work.

Workers' productivity simply means the relationship between inputs (information, materials, instruction etc) and outputs (tasks, decisions, etc) (David, 2004). It was also argued by the same author that since the production machinery in office consist primarily of people, then anything including noise that affects their conditions will likely have impact on their work performance. This argument is stressing that noise particularly conversational distractions that cause discomfort in office environment will affect negatively workers' productivity.

Despite the general interest in the study in the relationship between office conditions and workers' performance, there is still no accepted methodology to measure total factor productivity. However, current studies have highlighted some areas through which productivity can evaluated. The productivity metrics as contained in David, (2004) are;

(I) the speed which tasks are performed

(ii) the accuracy with which tasks are performed

(iii) the level of stress encountered by workers

(iv) The impact various stressors such as noise and vibration, have on the competence and endurance of workers over time 
(v) Employee turnover rates

(vi)Various attitudinal measures (high rate of satisfaction with workplace conditions usually correlates with increased productivity).

POE is generally defined as broad range of activities aimed at understanding how buildings perform once they built (Hewitt and Higgins, 2005).

The actual building performance weighted against intended objective can be ascertained by what is known as Post Occupancy Evaluation (POE).This is a control system that aimed at regulating occupant's comfort. It is very fundamental in controlling indoor environmental quality (IEQ) with specific implication on the overall performance and energy consumption. As highlighted by Lawrence and Keime (2016) the information served from POE can be used to improve the process of design for future construction through highlighting areas that need to be improved. Indoor Environmental Quality (IEQ) is an important building evaluation that moderate changes in building design and control of the indoor working environment, But there is also need to determine occupants' perception and comfort which focuses its implication on energy use (Koranteng, et al, 2010).Post Occupancy Evaluation (POE) is one such tool for achieving this objective.

\subsection{Study Area}

The study is carried out in Enugu State which is located in the South Eastern Nigeria. Enugu State is created in 1991 from the old Anambra State. Enugu state has a population of 722,644 according to 2006 census. The State has landmass of $4,267,837 \mathrm{~km} \mathrm{sq}$ and is located between latitudes $06^{\circ} 26^{\prime}$ and $06^{\circ} 30^{\prime} \mathrm{N}$ and longitudes $07^{\circ} 27^{\prime}$ and $07^{\circ} 37^{\prime} \mathrm{E}$ and lies east of Niger Delta [29].. The topography of Enugu city is characterized by undulating landscape with scattered hills and knolls and is located on a very high relief of about $228.9 \mathrm{~m}$ above sea level $[30,31]$.

The city falls within the tropical zone and is hot all year round with a mean annual temperature of between $22.7^{\circ} \mathrm{C}$ and $30.8^{\circ} \mathrm{C}$ and relative humidity between $40 \%$ and $80 \%$ [32] Enugu has a climate of hot humid type with the peak of humidity being experienced between March and November [30] As with the West African geographical land mass, Enugu experiences two major seasons, the rainy and dry seasons. During the dry season months of December and January, the city is affected by the Harttan;; a dust-laden trade wind from Sahara desert [32]

\subsection{Methodology}

\subsection{Research Design}

In this research, a quasi-experimental design (QED) was applied in order to obtain opinion rating of occupants of open and closed office spaces. The office blocks are selected to ensure that the relevant independent variables (like geographical location, exposure to noise level, building materials and year of completion), were the same expect for office sizes.

Three open office blocks and five closed office blocks of Enugu State secretariat complex were used. The office complex is located at the centre of the city and is about $2.2 \mathrm{~km}$ to Ogbete main market Enugu.

\subsection{Data collection}

Data was collected between October and September 2019.Survey questionnaires were administered to the workers to the selected offices through their sectional heads. Out of the 449 questionnaires administered, 390 were returned which represented about $86 \%$ of the total response rate (Table 4.1). 


Table 4.1 Response rate
\begin{tabular}{|l|c|c|c|c|c|c|l|l|l|}
\hline & $\begin{array}{l}\text { Open } \\
\text { 0ffice } \\
\text { block 1 }\end{array}$ & $\begin{array}{l}\text { Open } \\
\text { Office } \\
\text { block 2 }\end{array}$ & $\begin{array}{l}\text { Open } \\
\text { 0ffice } \\
\text { block 3 }\end{array}$ & $\begin{array}{l}\text { Closed } \\
\text { Office } \\
\text { block 1 }\end{array}$ & $\begin{array}{l}\text { Closed } \\
\text { 0ffice } \\
\text { block 2 }\end{array}$ & $\begin{array}{l}\text { Closed } \\
\text { Office } \\
\text { block 3 }\end{array}$ & $\begin{array}{l}\text { Closed } \\
\text { 0ffice } \\
\text { block 4 }\end{array}$ & $\begin{array}{l}\text { Closed } \\
\text { 0ffice } \\
\text { block 5 }\end{array}$ & $\begin{array}{l}\text { Total } \\
\text { No of office blocks }\end{array}$ \\
\hline $\begin{array}{l}\text { Questionnaires } \\
\text { administered }\end{array}$ & 68 & 88 & 64 & 50 & 60 & 38 & 42 & 39 & 449 \\
\hline Responses & 61 & 80 & 60 & 45 & 51 & 29 & 31 & 33 & 390 \\
\hline$\%$ Rate & $89 \%$ & $90 \%$ & $93 \%$ & $90 \%$ & $85 \%$ & $76 \%$ & $73 \%$ & $84 \%$ & $86 \%$ \\
\hline
\end{tabular}

\section{DATA PRESENTATION AND ANALYSIS OF RESULT}

\subsection{Analysis of the first research objective}

which is ".To assess the influence of indoor environmental quality (EQ) on acoustic comfort of open and closed office workers in Enugu state".

Table 4.2; Shows the Frequency Distribution Table where VGE= Very Great Extent,

$\mathbf{G E}=$ Great Extent, UD=Undecided, LE- Low Extent, VLE= Very Low Extent, W= Weighting and $\mathbf{W F}=$ Weighted Frequency

\begin{tabular}{|c|c|c|c|c|c|c|c|c|c|c|}
\hline $\mathbf{S} / \mathbf{N}$ & $\begin{array}{l}\text { Indoor environmental quality can } \\
\text { influence acoustic comfort of open } \\
\text { and closed office workers in Enugu } \\
\text { state. }\end{array}$ & $\mathbf{W}$ & $\begin{array}{l}\text { VGE } \\
5\end{array}$ & $\mathbf{4}^{\text {GE }}$ & $3^{\text {UD }}$ & ${ }_{2}^{\mathbf{L E}}$ & $\begin{array}{l}\text { VLE } \\
1\end{array}$ & $\sum \mathbf{F X}$ & $\dot{X}$ & DECISION \\
\hline 1 & $\begin{array}{l}\text { Thermal qualities of office buildings } \\
\text { can influence noise distraction of the } \\
\text { workers. }\end{array}$ & $\begin{array}{l}\text { F } \\
\text { WF }\end{array}$ & $\begin{array}{l}100 \\
500\end{array}$ & $\begin{array}{l}153 \\
612\end{array}$ & $\begin{array}{l}92 \\
276\end{array}$ & $\begin{array}{l}36 \\
72\end{array}$ & $\begin{array}{l}9 \\
9\end{array}$ & $\begin{array}{l}390 \\
1490\end{array}$ & 3.76 & ACCEPT \\
\hline 2 & $\begin{array}{l}\text { The extent of visual quality of office } \\
\text { spaces can affect noise distraction of } \\
\text { the workers }\end{array}$ & $\begin{array}{l}\text { F } \\
\text { WF }\end{array}$ & $\begin{array}{l}48 \\
240\end{array}$ & $\begin{array}{l}40 \\
160\end{array}$ & $\begin{array}{l}44 \\
132\end{array}$ & $\begin{array}{l}146 \\
292\end{array}$ & $\begin{array}{l}112 \\
112\end{array}$ & $\begin{array}{l}390 \\
936\end{array}$ & 2.40 & REJECT \\
\hline \multirow[t]{2}{*}{3} & $\begin{array}{l}\text { Air quality of office spaces has } \\
\text { significant impact on the noise } \\
\text { distraction of workers }\end{array}$ & $\begin{array}{l}\text { F } \\
\text { WF }\end{array}$ & $\begin{array}{l}112 \\
560\end{array}$ & $\begin{array}{l}123 \\
492\end{array}$ & $\begin{array}{l}98 \\
294\end{array}$ & $\begin{array}{l}36 \\
72\end{array}$ & $\begin{array}{l}21 \\
21\end{array}$ & $\begin{array}{l}390 \\
1439\end{array}$ & 3.68 & ACCEPT \\
\hline & Grand mean & & & & & & & & 3.28 & ACCEPT \\
\hline
\end{tabular}

\section{Source: field survey computation}

In Table 4.2.three questionnaire items were used to answer objective one, it is seen that two of the questionnaire items tested have value above the criterion mean of 3.0. The grand mean total is 3.28 which implies that all the instruments listed are the identified ways indoor environmental quality (IEQ) can influence acoustic comfort of open and closed office workers in Enugu state.

4.31 Analysis of the second research objective which is ".To assess the effect of noise distraction on the satisfaction of open and closed office workers of Enugu state". 
Table 4.3; Shows the Frequency Distribution Table for analysis of the second Objective .

\begin{tabular}{|c|c|c|c|c|c|c|c|c|c|c|}
\hline $\mathbf{S} / \mathbf{N}$ & $\begin{array}{l}\text { Objective } 2 \text {, "Noise distraction in an } \\
\text { open and closed office has effect on the } \\
\text { satisfaction of workers of Enugu } \\
\text { state". }\end{array}$ & $\mathbf{W}$ & $\begin{array}{l}\text { VGE } \\
5\end{array}$ & $\begin{array}{l}\text { GE } \\
4\end{array}$ & $\begin{array}{l}\text { UD } \\
3\end{array}$ & E ${ }_{1}^{\text {VLE }}$ & $\left.\sum \mathbf{F}\right\rangle$ & & $\dot{X}$ & $\begin{array}{l}\text { DECISIO } \\
\mathbf{N}\end{array}$ \\
\hline 4 & $\begin{array}{l}\text { Human generated noise in an office } \\
\text { influences comfort of the workers }\end{array}$ & $\begin{array}{l}\text { F } \\
\text { WF }\end{array}$ & $\begin{array}{l}134 \\
670\end{array}$ & $\begin{array}{l}92 \\
368\end{array}$ & $\begin{array}{l}89 \\
267\end{array}$ & $\begin{array}{l}35 \\
70\end{array}$ & $\begin{array}{l}40 \\
40\end{array}$ & $\begin{array}{l}390 \\
1415\end{array}$ & 3.62 & ACCEPT \\
\hline 5 & $\begin{array}{l}\text { Machine oriented noise can also } \\
\text { influence the comfort of the workers of } \\
\text { Enugu State. }\end{array}$ & $\begin{array}{l}\mathbf{F} \\
\mathbf{W F}\end{array}$ & $\begin{array}{l}155 \\
775\end{array}$ & $\begin{array}{l}85 \\
340\end{array}$ & $\begin{array}{l}\mathbf{5 0} \\
150\end{array}$ & $\begin{array}{l}60 \\
120\end{array}$ & $\begin{array}{l}40 \\
40\end{array}$ & $\begin{array}{l}390 \\
1425\end{array}$ & 3.65 & ACCEPT \\
\hline 6 & $\begin{array}{l}\text { Impact noise like door opening/closing } \\
\text { and walking on hard surface, etc create } \\
\text { great discomfort on the workers . }\end{array}$ & $\begin{array}{l}\text { F } \\
\text { WF }\end{array}$ & $\begin{array}{l}100 \\
500\end{array}$ & $\begin{array}{l}100 \\
400\end{array}$ & $\begin{array}{l}98 \\
294\end{array}$ & $\begin{array}{l}91 \\
182\end{array}$ & 1 & $\begin{array}{l}390 \\
1377\end{array}$ & 3.53 & ACCEPT \\
\hline & Grand Total & & & & & & & & 3.6 & ACCEPT \\
\hline
\end{tabular}

\section{Source: field survey computation}

Three questionnaire items were used to answer objective two. All the items had mean ratings above 3.0. The grand mean rating was 3.6 which is also above the criterion mean. Based on this, we conclude that the identified factors are the effect of noise distraction on the comfort of office workers of Enugu state.

4.32 Analysis of the third research objective which is ".To evaluate the effect of noise distraction on task performance of office workers of Enugu state"

Table 4.4; Shows the Frequency Distribution Table for analysis of the third Objective.

\begin{tabular}{|c|c|c|c|c|c|c|c|c|c|c|}
\hline $\mathbf{S} / \mathbf{N}$ & $\begin{array}{l}\text { The effect of noise distraction on } \\
\text { task performance of office workers } \\
\text { of Enugu state. }\end{array}$ & $\mathbf{W}$ & $\begin{array}{l}\text { VGE } \\
5\end{array}$ & $\begin{array}{l}\text { GE } \\
4\end{array}$ & $\begin{array}{l}\text { UD } \\
3\end{array}$ & $\mathbf{E}$ & & $\sum \mathbf{F X}$ & $\dot{X}$ & DECISION \\
\hline & Grand mean & & & & & & & & 3.29 & ACCEPT \\
\hline
\end{tabular}

\section{Source: field survey computation}


In Table 4.4. three questionnaire items were used to answer objective three, All the questionnaire items tested have values above the criterion mean of 3.0 except third questionnaire item which has a mean rate of 2.90, Which implies that all the instruments listed except instrument in the questionnaire item three are the identified effect of noise distraction on task performance of office workers of Enugu state.

\section{Summary of findings}

Table 4.2 shows the responses of the respondents on the influence of indoor environmental quality (EQ) on acoustic comfort of open and closed workers in Enugu state. Looking at the questionnaire items which answers objective one, item 1, and 3, with a mean score of 3.76, and 3.68 while questionnaire item 2 had a mean score of 2.40.The mean rating of all the items is above 3.0 which indicates that all Indoor Environmental Quality (IEQ) factors of office buildings, except visual quality, have influence on acoustic comfort of open and closed office workers in Enugu state. Hence the researcher concludes that all the listed items are the factors of indoor environmental quality that influence acoustic comfort of open and closed office workers in Enugu state.

Table 4.3: shows the effect of noise distraction on the satisfaction of open and closed office workers of Enugu state, Questionnaire items 4,5,6 with a mean score of 3.62, 3.65 and 3.53 has a mean rating above 3.0. The grand mean was estimated to be 3.6. which implies that human generate noise in an office, machine oriented noise and door opening/ closing are the factors that influence comfort of office workers in Enugu state. Hence the researcher concludes that the listed items are the basic effect of noise distraction on the satisfaction of open and closed office workers in Enugu state.

Table 4.4: shows the effect of noise distraction on task performance of office workers of Enugu state, item 7, 8 and 9 with the mean score of 3.49, 3.50 and 2.90 had a mean rating above 3.0 except questionnaire item 9 which has a mean score of 2.90. it implies that the speed of office task, the level of stress encountered and office workers turnover rate are the identified effect of noise distraction on task performance of office workers of Enugu state. Hence the researcher conclude that the identified factors are the effect of noise distraction on task performance of office workers of Enugu state.

\section{Discussion of the findings \\ Objective one: To assess the influence of indoor environmental quality (EQ) on acoustic comfort of open and closed office workers in Enugu state.}

From the findings, thermal quality of office building, the extent of visual quality of office spaces and air quality of office spaces are the identified influence of indoor environmental quality on acoustic comfort of open and closed office workers in Enugu state. This findings is in consonance with the work of Loewen and Suedfeld (1992) who believes that design techniques for noise prevention are absorption of sound by ceiling tiles, blocking of sound using workstation panels and sound covering using electronics.

Objective two: To assess the effect of noise distraction on the satisfaction of open and closed office workers of Enugu state. The findings of this work showed that human generated noise in an office, machine oriented noise and impact noise like door opening/closing are the identified effect of noise distraction on the satisfaction of open and closed office workers of Enugu state. This supports the work of Cherow (1991) who believes that office related noise have an impact on physical health, and brings psychological distractions and annoyance to office workers which could reduce their productivity.

Objective three: To evaluate the effect of noise distraction on task performance of office workers of Enugu state. The findings revealed that the speed in which office task is performed, the level of stress encountered by workers and the office workers turnover rates 
are the identified effect of noise distraction on task performance of office workers of Enugu state. The findings has similarity with the work of passhier (1993) who believes that feeling of resentment, displeasure, discomfort, dissatisfaction or offense that occur when noise interfere with someones thoughts, feelings or daily activities, affect the overall productivity

\section{Conclusion/Recommendations}

The study is aimed to examine the influence of noise on the performance of open and closed office workers in Enugu state. From the findings, the following conclusions were drawn:

1. Thermal qualities of office buildings, the extent of visual quality of office spaces and air quality of office spaces are the identified ways indoor environmental quality influences acoustic comfort of open and closed office of workers in Enugu state. The identified factors limits indoor environmental quality on acoustic comfort of open and closed office workers in Enugu state.

2. Human generated noise in an office, machine oriented noise and impact noise like door opening/closing and working on hard surfaces etc are the identified effect of noise distraction on the satisfaction of open and closed office workers of Enugu state. The listed factors cause noise distraction and dissatisfaction of open and closed office workers of Enugu state.

3. The speed in which office task is performed, the level of stress encountered by workers and the office workers turnover rate are the effect of noise distraction on task performance of office workers of Enugu state. Hence the researcher concluded that the listed factors are the identified effect of noise distraction on task performance of office workers of Enugu state.

\section{Appendix 1}

\section{Survey Questionnaires}

The questionnaires used for the study are semi-structured closed and multiple choices questions. The respondents were required to just tick. The focuses were on the respondents' general satisfaction and perception of office acoustic comfort as it affects their task performance. Table 4.2 highlights some basic contents of the questionnaires.

Table 4.2 Variables and survey questions, answers and assigned values.

\begin{tabular}{|c|c|c|c|c|c|c|}
\hline $\mathbf{S} / \mathbf{N}$ & $\begin{array}{l}\text { Objective 1"To determine the influence of Indoor } \\
\text { Environmental Quality (IEQ) on the noise distraction of } \\
\text { office workers of Enugu State". Item: relationship between } \\
\text { indoor Environmental Quality (IEQ) and noise distraction }\end{array}$ & $\begin{array}{l}\text { VGE } \\
1\end{array}$ & $\begin{array}{l}\text { GE } \\
2\end{array}$ & $\begin{array}{l}\text { UD } \\
\mathbf{3}\end{array}$ & $\begin{array}{l}\text { LE } \\
4\end{array}$ & $\begin{array}{l}\text { VLE } \\
5\end{array}$ \\
\hline 1 & $\begin{array}{l}\text { Thermal qualities of office buildings can influence noise } \\
\text { distraction of the workers. }\end{array}$ & & & & & \\
\hline 2 & $\begin{array}{l}\text { The extent of visual quality of office spaces can affect noise } \\
\text { distraction of the workers }\end{array}$ & & & & & \\
\hline 3 & $\begin{array}{l}\text { Air quality of office spaces has significant impact on the } \\
\text { noise distraction of workers }\end{array}$ & & & & & \\
\hline
\end{tabular}

Table 4.3 Variables and survey questions, answers and assigned values..

\begin{tabular}{|l|l|l|l|l|l|l|}
\hline S/N & $\begin{array}{l}\text { Objective 2; "To evaluate the effect of noise distraction on VGE } \\
\text { the comfort of office workers of Enugu State" Item: } \\
\text { relationship between office noise distractions and general } \\
\text { comfort of the workers }\end{array}$ & $\begin{array}{l}\mathbf{1} \\
\mathbf{2}\end{array}$ & $\begin{array}{l}\mathbf{3} \\
\text { Human generate noise in an office influences comfort of } \\
\text { office workers }\end{array}$ & $\begin{array}{l}\mathbf{4} \\
\mathbf{4}\end{array}$ & $\mathbf{5}$ \\
\hline $\mathbf{2}$ & $\begin{array}{l}\text { Machine oriented noise has more influence of the comfort of } \\
\text { the workers }\end{array}$ & & & & & \\
\hline $\mathbf{3}$ & $\begin{array}{l}\text { Impact noise like door opening/closing, walking on hard } \\
\text { surfaces, etc create great discomfort on the workers }\end{array}$ & & & & \\
\hline
\end{tabular}


Table 4.4 Variables and survey questions, answers and assigned values.

\begin{tabular}{|l|l|l|l|l|l|l|}
\hline S/N & $\begin{array}{l}\text { Objective 3 "To evaluate the effect of noise distraction on } \\
\text { task performance of office workers of Enugu State"Item: } \\
\text { relationship between office noise distractions and general } \\
\text { performance of the workers } \\
\text { - }\end{array}$ & $\begin{array}{l}\mathbf{1} \\
\text { The speed in which office task is performed is affected by } \\
\text { noise distraction }\end{array}$ & $\begin{array}{l}\text { UD } \\
\mathbf{3}\end{array}$ & $\begin{array}{l}\text { LE } \\
\mathbf{4}\end{array}$ & $\mathbf{5}$ \\
\hline $\mathbf{1}$ & $\begin{array}{l}\text { The level of stress encountered by workers is influenced by } \\
\text { noise distraction }\end{array}$ & & & & & \\
\hline $\mathbf{3}$ & $\begin{array}{l}\text { The office workers turnover rates are influenced by noise } \\
\text { distraction. }\end{array}$ & & & & \\
\hline
\end{tabular}

\section{References}

1. AlHorr, Y. Arif, M, Katafygiotou, M. Mazroei, A. Kaushik, A. K. and Elsarrag, E. (2016), Impact of indoor environmental quality on occupant well-being and comfort; a review of the literature. University of Salford Manchester http;/dx.doi,org/10.1016/j,ijsbe,2016,03,006

2. Andersen, R. V. Toftum, J. Andersen, K.K. andOlesen, B. W., (2009), Survey of occupant behavior and control of indoor environment in Danish dwellings, Energy and Buildings. 41(1) 11-16.

3. Andersen, K. (2008), Classroom acoustic; a first step toward education for all.J.Acoust. Soc. Am. 124 (40 2587-2588.

4. (Armstrong, (1997), A case study of office speech noise distraction and workers productivity, Summary of an independent, 6-month longitudinal field study.

5. Basener et al, (2014), Authority and ono-authority effects of noise on health, The Lancet, 383 99925), 1325-1332

6. Bluyssen, P. M. Aris, M. Dommelen, P. (2011a). Comfort of workers in office buildings, the European HOPE project.Building Environment 46(1) 280-288.

7. Cherow, E (1991), Combating noise in the 90s at National Strategy for the United States, Rocksville, MD American Speech Hearing Association.

8. David, M.S. (2004), Productivity; How acoustics affect workers' performance in offices and open areas.

9. De-Giuli , V. Da-Pos, O De-Carli, M. (2012), Indoor environmental quality and pupil perception in Italian primary schools. Building and Environment, 56 335-345.

10. EPA, 1981, Noise effects handbook, A desk reference to health and welfare, Effects of noise EPA, 550/982-106, Washington DC, U S Environmental Protection Agency Office of Noise Abatement and Control.

11. Environmental Protection Agency EPA, (2000), Indoor air quality and student performance, United States Environmental Protection Agency, Indoor Environment Division office of Radiation and Indoor Air, Washington D, C 402-K-03-006.

12. Evans, Gary, W. and Johnson, D. (2000), Stress and Open-Office Noise, Journal of Applied Psychology, 85 (5) 779-783

13. Jensen, K.L. Aren, E. s and Zagreus, L. (2005), Acoustical quality in office workstations, As assessed by occupants surceys. Proceedings Indoor air, International Centre for Indoor Environment and Energy, Technical University of Denmark, Denmark www, ie dtu.dk.

14. Hewitt, D. and Higgins, C. ( 2005), A Market-Friendly Post-Occupancy Evaluation; BUILDING Performance Report (Green buildings) 97204, 503.

15. Koranteng, C. (2010), The evaluation of occupants' behaviour and preference in office buildings in Ghana, Journal of Science Technology, Ghana, 30(10). 
16. (Landstrom, U. Akerlund, E. Kjeliber, A. and Tesarz, M. (1995), Exposure level, total components, and noise annoyance in working environments. Environ. Int. 21(3) 265-275

17. Lawrence, R. and Keime ,C. (2016), Bridging the gap between energy and comfort; Postoccupancy evaluation of two higher education buildings in Sheffield; Energy Building, $130651-666$.

18. Leech, J.A. Nelson, W.C. Burnett, R.T. Aaron, S. andRaizenne, M.E. (2002), It's about time; a comparison of Canadian and American time-activity patterns, Journal Expo, Annual Environ Episdemiol,. 12(6) 427-432

19. Loewen, I. J. and Suedfeld, P. (1992), Cognitive and arousal effects of masking office noise. Environmental Behaviour, 24(3), 381-395.

20. Morkporkpor, D. S. Danie, V. K. D.1 and Augustus, A. L. (2017), Evaluation of Occupant Comfort in Office Buildings in Ghana. International Journal of Sustainable and Green Energy, 6(6) 93-103

21. Nyunling, P. and Cheung, C. M. (2007), Study of noise perception and distraction in office. International Association of societies pf design research .The Hong Kong Polytechnics

22. Salter, C. Powell, K. Begault, D .and Alavarado, R. (2003), Case studies of a method for predicting speech privacy in the contemporary workplace, Centre for The Built Environment, UC Berkeley,

23. Schiavon, S. and Altomonte, S. (2014), Influence of factors unrelated to environmental quality on occupant satisfaction in LEED and non-LEED certified buildings. Building Environs 77, 148-159

24. Stansfeid, S.A. and Matheson, M.P. (2003), Noise pollution; Non-authority effects on health, British Medical Bulletin, 68 243-257.

25. Strelets, K. Periova, E. Platonova, M. Pankova, A. Romero, M. and Al- Shabab, M. S. (2016), PostOccupancy Evaluation (POE) and Energy Conservation Opportunities (ECOs). Study for Three Facilities in Procedia Engineering, 165, 1568-1578.

26. Sundstrom, E. Town, J.P, Rice, R.W. Osborn, D,P. and Brill, M. ( 1994), Office noise, satisfaction, and performance .Environ. Behav. 26(2), 195-222.

27. Veitch, J.A. Bradley J.S., Legault, L.M. Norcros, S.s and Svec J.M.,( 2002), Masking speech in Open-Plan Offices with Simulated Ventilation Noise; Noise level and Spectral Composition Effects on Acoustic Satisfaction. Institute for Research in Construction.

28. Yousef, A. Mohammed, A. Martha, K. Ahmed, M. Amit, K. and Esam, E. (2016), Impact of indoor environmental quality on occupant well-being and comfort; A review of the literature. International Journal of Sustainable Environment, 5 (1), 1-11 